Original Research Paper

\title{
Pendidikan Dan Latihan Menghitung Validitas, Reliabilitas, Tingkat Kesukaran, Daya Beda Soal Bagi Guru PPKn SMAN Se-Kota Mataram
}

\author{
Ahmad Fauzan $^{1 *}$, Hariyanto ${ }^{1}$, Rispawati ${ }^{1}$ I Nengah Agus Tripayana ${ }^{1}$ \\ ${ }^{I}$ Program Studi PPKn, FKIP Universitas Mataram, Mataram, Indonesia.
}

https://doi.org/10.29303/jpmpi.v3i2.982

Sitasi: Suwardji., Tejowulan, S., Muslim, B., Idrus, A. A., Syukur, A., Raksun, A \& Parman. (2021). Pemberdayaan Masyarakat Dalam Rehabilitasi Hutan dan Lahan Kritis di Wilayah Sekaroh Lombok Timur: Belajar Dari Pengalaman Masyarakat. Jurnal Pengabdian Magister Pendidikan IPA, 4(4)

\author{
Article history \\ Received: 15 September 2021 \\ Revised: 20 September 2021 \\ Accepted: 27 September 2021 \\ *Corresponding Author: \\ Ahmad Fauzan, Program \\ Studi PPKn, FKIP Universitas \\ Mataram, Mataram, Indonesia. \\ Email: \\ ahmadfauzan18@unram.ac.id
}

\section{Pendahuluan}

Soal PPKn Jenjang SMAN yang memiliki kualitas terstandar merupakan salah satu upaya peningkatan mutu pendidikan. Pendidikan menjadi salah satu wadah bagi siswa untuk dapat meningkatkan potensi diri bagi setiap individu, kepribadian baik, memiliki soft skill yang memadai, serta menjadi bangsa yang cerdas dan bermartabat.(Fauzan et al., 2021). Dalam rangka

\begin{abstract}
:
Tujuan pengabdian dilakukan ini adalah; 1) meningkatkan kemampuan menghitung validitas, realibilitas, tingkat kesulitan dan daya beda suatu soal bagi guru PPKn pada jenjang SMAN se kota mataram. 2) para guru PPKn jenjang SMAN se Kota mataram menyadari bahwa soal yang telah dihitung validitas, realibilitas, tingkat kesulitan dan daya bedanya, maka mereka telah memiliki soal terstandar. 3) para guru PPKn jenjang SMAN se kota mataram merintis dan membangun Bank soal terstandar dan bank sola PPKn.4) para guru PPKn jenjang SMAN se Kota Mataram memiliki kesadaran untuk memperbaiki soal yang memiliki validitas, realibilitas, tingkat kesukaran dan daya beda yang jelek. Metode pengabdian menggunakan pendekatan studi kasus pengalaman guru terkait dengan soal uraian maupun soal pilihan ganda. Hasil dilakukannya pengabdian ini adalah tidak semua guru suka hitungan statistic, maka banyak guru hanya mengandalkan validitas dan reliabilitas soal secara rasional saja dengan tukar pikiran di antara guru PPKn dalam wadah Musyawarah Guru Mata Pelajaran PPKn. Dengan disediakan materi pengabdian kepada masyarakat secara rinci renik, maka kegiatan Pendidikan Dan Latihan menghitung Tingkat Kesuliatan dan Daya Beda soal disertai contoh menghitung validitas dengan uji product moment dan uji reliabilitas test-retest dengan uji product moment menjadi sangat menarik dan menjadi tantangan tersendri bagi masing-masing peserta.
\end{abstract}

Keywords: Validitas, Reabilitas, Daya beda soal, dan guru PPKn mendapatkan soal PPKn yang terstandar diperlukan pengetahuan dan pengalaman terkait dengan menghitung validiytas, reliabilitas, tingkat kesulitasn, dan daya beda soal. Validitas soal terkait dengan kemampuan soal untuk mengukur aspek yang ingin diukur. Relibilitas soal terkait dengan hasil pengukuran dengan soal tersebut benar-benar dapat dipercaya untuk mengukur penguasaan pengetahuan oleh siswa. Tingkat kesulitan soal terkait mengklasifikasikan soal yang mudah, sedang, dan sulit, Sedangkan daya beda soal terkait dengan bahwa soal tersebut benar-benar dapat 
membedakan siswa yang pandai, sedang, dan siswa yang lemah. Hal ini berarti bahwa setiap guru sangat memerlukan pengetahuan dalam bentuk pendidikan dan pengalaman melalui pelatihan. Dalam rangka meningkatkan kualitas pemahaman dan keterampilan menghitung validitas, reliabilitas, tingkat kesulitan, dan daya beda soal, para peserta didampingi oleh Tim Pengabdian Pada masyarakat mulai dari pendidikan sampai selesai penjadwalan pelatihan yang dilaksanakan melalui daring Whats App.akibat pandemic Covid 19.

Kegiatan evaluasi pembelajaran pada Mata Pelajaran PPKn di sekolah sedemikian lumrah, sehingga berdampak cara kerja yang otomatis. Setiap guru PPKn selalu membuat soal baik yang berbentuk test uraian untuk ulangan harian dan berbentuk test pilihan ganda untuk ulangan akhir semester. Kegiatan ini selalu dilakukan guru, tanpa memikirkan apakah soal yang digunakan guru telah fungsional dengan komponen proses pembelajaran lainnya. Dalam dunia pendidikan sering terjadi salah penafsiran terhadap hasil ujian para siswanya. Pada umumnya apabila siswa dalam ujian mendapat nilai ujian yang baik, maka ditafsirkan bahwa siswanya pandai. Sedangkan apabila hasil ujian para siswa jelek, maka ditafsirkan bahwa siswa berkemampuan lemah. Pendapat di atas ada benarnya, namun tidak sepenuhnya benar. Dalam pelaksanaan ujian, jika soalnya tingkat kesulitan mudah semua dengan sendirinya para siswanya mampu menjawab dengan baik. Fatalnya lagi soal yang digunakan guru tidak memiliki daya beda yang baik, dalam arti siswa yang pandai dengan siswa yang lemah tidak ada perbedaanya. Dimana siswa benar menjawab karena kunci jawaban diketahui karena dibimbing oleh batang tubuh soal. Disisi lain jika guru menerapkan soal yang tingkat kesulitan sangat tinggi, maka otomatis hasil ujian para siswanya jelek semua atau siswa yang berkategori pandai tidak ada bedanya dengan siswa yang lemah karena semua tidak dapat menjawab soal yang diberikan guru. Hal ini berarti tingkat kesulitan soal dan daya beda setiap soal penting dinanlisis atau dihitung oleh guru yang membuat soal termasuk bagi guru PPKn SMAN Se Kota Mataram. Melalui pendidikan dan latihan menghitung tingkat kesulitan dan daya beda ini, maka para guru PPKn SMAN se Kota Mataram akan memiliki dan dapat membangun Bank Soal. Selanjutnya dalam penggunaannya para guru dapat menggunakan soal yang proporsional. Proporsi soal yang proporsonal ditandai dengan jumlah soal yang sulit $20 \%$, sedang $50 \%$, dan soal yang mudah porsinya $30 \%$. Dengan demikian secara akademik apabila siswa telah mencapai benar minimal $75 \%$, maka berarti benar telah mencapai Kriteria Ketuntasan Minimal 75. Hal ini re;evan dengan Teori Benyamin S Bloom yang mengatakan bahwa ketuntasan minimal yang harus dicapai setiap siswa minimal $75 \%$.

Test yang digunakan di sekolah merupakan salah satu bentuk yang senantiasa digunakan untuk mengukur ketercapaian indikator pencapaian kompetensi sebagai penjabaran operasional kompetensi dasar. Sesuai dengan pendapat Zainul Asmawi dan Mulyana Agus (2004: 1.3) yang menyatakan bahwa test yang dilaksanakan di sekolah merupakan perangkat kegiatan yang dimaksudkan untuk mengukur ketercapaian tujuan pendidikan yang telah dirancang secara seksama dalam kurikulum. Sebagai alat ukur hasil belajar, soal dalam bentuk test yang dibuat dan digunakan sebenarnya wajib dihitung tingkat kesulitan dan daya bedanya, karena ada kewajiban guru harus melakukan perbaikan terhadap test yang kualitasnya tidak memenuhi syarat sebagai soal test yang baik. Hal ini sesuai dengan pendapat Hariyanto (1984: 85) bahwa untuk menyusun test yang baik dan representatif, maka langkah-langkah menyusun test berikut ini harus dilaksanakan:

1. Mengumpulkan dan menginventarisasikan Indikator Pencapaian Kompetensi

2. Menginventarisasikan materi pembelajaran

3. Menyusun bagan perincian test

4. Menyusun test

5. Menelaah test

6. Membuat kunci jawaban

7. Menganalisa hasil test

8. Perbaikan dan penyempurnaan test

Pada umumnya para guru pada waktu ujian semester atau akhir semester, guru menggunakan soal yang berbentuk pilihan ganda, karena keterbatasan waktu untuk memeriksa hasil ujian. Namun demikian, guru hanya mengoreksi benar atau salahnya saja dan tidak menghitung validitas, reliabilitas, tingkat kesulitan dan daya beda soal yang telah digunakan sebagai alat pengukuran. Dari delapan langkah di atas, maka tahap menganalisa hasil test berarti guru harus menghitung:

1. Validitas soal

2. Reliabilitas soal 
3. Tingkat kesulitan soal

4. Daya beda soal

Selanjutnya dari hasil perhitungan di atas, maka soal yang berkualitas baik dijadikan "Bank Soal". Sedangkan soal yang tidak valid, tidak reliable, tingkat kesulitan dan daya beda tidak baik, ada kewajiban guru untuk melakukan review dan revisi. Hal ini sesuai dengan pendapat Hariyanto (1984: 106) yang mengatakan bahwa test yang perlu diperbaiki dan disempurnakan adalah test yang memiliki:

1. Koefisien Daya Beda kurang dari $20 \%$

2. Indek derajat kesukaran kurang dari $10 \%$ dan atau lebih dari $90 \%$

3. Proporsi antara test yang mudah, sedang, dan yang sukar tidak serasi, dimana proporsi yang serasi mudah $30 \%$, sedang $50 \%$, dan sukar $20 \%$.

4. Konstruksi soal kalimat kurang jelas

5. Kurang sesuai dengan indikator pencapaian kompetensi

6. Test itu sendiri Kunci Jawabannya terlalu jelas atau mudah ditebak

Selain hal di atas, terutama soal yang dalam bentuk uraian/ essay termasuk soal test pilihan ganda harus representatif terhadap skope materi pembelajaran dan tingkat kemampuan siswa yang belajar. Dalam kaitan penghitungan validitas, reliabelitas, tingkat kesulitan dan daya beda, Ghony M Djunaidi (1985: 179) menggunakan analisa item. Selanjutnya dikatakan analisa item adalah prosedur untuk meningkatkan daya tahan dan berlakuknya suatu tes atau soal.

Berdasarkan latar belakang yang telah diuraikan di atas, maka Pendidikan Dan Pelatihan Menghitung validitas, reliabilitas, tingkat kesulitas dan daya beda soal Bagi Guru PPKn SMAN Se Kota Mataram sangat strategis dan krusial untuk terbentuknya Bank Soal dan hasil pengukuran pembelajaran yang bermutu.

\section{Metode}

Dalam rangka memecahkan permasalahan yang dihadapi para Guru PPKn SMP Se-Kota Mataram terakit dengan soal yang memiliki tingkat kesulitan baik, daya beda, dan proporsi soal mudah, sedang, dan sulit, maka Tim Pengabdian Pada
Masyarakat Program Studi PPKn menggunakan pendekatan studi kasus pengalaman guru terkait dengan soal uraian maupun soal pilihan ganda. Kegiatan diawali dengan Brainstorming Problematik Soal PPKn di Jenjang SMP Tahap berikutnya secara kolaborative memperbaiki dan mengembangkan teori terkait Langkah-Langkah Menyusun Soal dan Kriteria Tes yang baik.

Metode pelaksanaan kegiatan pengabdian pada masyarakat Program Studi PPKn FKIP Universitas Mataram akan dilaksanakan melalui pendidikan dan dilanjutkan pelatihan.

\section{Tahap Pendidikan:}

1. Para peserta dibagikan Hand-Out terkait Langkah-Langkah Menyusun Test Dan Syarat Test yang baik sekaligus diberi bantuan pulsa

2. Para peserta memyampaikan problematik terkait dengan soal beebentuk test melalui WhatsApp, karena tidak boleh tatap muka dampak Covic 19

3. Secara individu peserta mempelajari dan dilanjutkan kolaborative membahas masingmasing soal test yang digunakan untuk mengukur hasil pembelajaran lewat WhatsApp

4. Peserta dibagikan Rumus Menghitung Tingkat Kesulitan dan Daya Beda soal dilengkapi contoh

5. Peserta diberi kesempatan berpartisipasi untuk meningkatkan pengetahuan dan wawasan terkait dengan Validitas, Reliabilitas, Tingkat Kesulitan, Daya Beda Soal, dan Representaifitas soal

\section{Tugas Mandiri:}

Menghitung tingkat kesulitan dan daya beda soal masing-masing pengalaman guru di SMA Negeri (selama 6 hari kerja).

\section{Tahap Latihan:}

1. Diawali dengan menunjukkan hasil kerja mandiri ke forum kegiatan dengan share ke peserta lainnya

2. Produk hasil kerja saling tukar dengan di antara peserta untuk dapat diberi masukan

3. Bersama Tim Pengabdian Pada Masyarakat berdiskusi terhadap produk menghitung tingkat validitas, reliabilitas soal, tingkat kesulitan dan daya beda soal

4. Review dan Revisi Hasil Kerja para Guru PPKn SMA Negeri Se Kota Mataram

5. Penyampaian Rencana Program Pengabdian Kepada Masyarakat berikutnya yang diharapkan Oleh peserta sebagai anggota Musyawarah Guru 
Mata Pelajran PPKn jenjang SMA Negeri Se Kota Mataram

6. Kegiatan penutup dan dibagikan Sertifikat Peserta

\section{Hasil Kegiatan Pengabdian Pada Masyarakat}

Kegiatan pengabdian kepada masyarakat diawali dengan pengiriman Surat kepada Kepala Sekolah SMANegeri melalui Ketua MGMP PPKn SMA sebanyak 15 untuk mendukung pelaksanaan Pendidikan dan Pelatihan tertanggal 1 September 2020 dengan menugaskan Guru PPKn, yang dilaksanakan pada Hari Jum'at, 1 September 2020.

\section{Hasil dan Pembahasan}

Tabel 1. Jadwal Pendidikan Dan Latihan Menghitung Validitas, Reliabilitas,Tingkat Kesulitan , dan Daya Beda Soal Bagi Guru PPKn SMA Negeri Se Kota Mataram Tahun 2020

\begin{tabular}{|c|c|c|c|c|}
\hline No & Hari, Tanggal, Waktu & $\begin{array}{l}\text { Kegiatan, Materi Pendidikan } \\
\text { Dan Latihan }\end{array}$ & $\begin{array}{l}\text { Bentuk } \\
\text { Kegiatan }\end{array}$ & Tempat Kegiatan \\
\hline 1 & $\begin{array}{l}\text { Selasa 1 September } 2020 \\
08.00-12.00 \text { Wita }(4,0 \text { jam })\end{array}$ & $\begin{array}{l}\text { Menghitung Validitas Soal } \\
\text { Nara Sumber: Drs. Hariyanto, } \\
\text { M.Pd dan Ahmad } \\
\text { Fauzan,S.Pd., M.Pd }\end{array}$ & Invidual & $\begin{array}{l}\text { Rumah masing-masing atau } \\
\text { sekolah tempat bertugas }\end{array}$ \\
\hline 2 & $\begin{array}{l}\text { Rabu } 2 \text { September } 2020 \\
08.00 \text { - } 12.00 \text { Wita }(4,0 \text { jam })\end{array}$ & $\begin{array}{l}\text { Menghitung Reliabilitas Soal } \\
\text { Nara Sumber: Drs Hariyanto, } \\
\text { M.Pd } \\
\text { Dan Ahmad Fauzan, S.Pd., } \\
\text { M.Pd }\end{array}$ & Individual & $\begin{array}{l}\text { Rumah masing-masing atau } \\
\text { sekolah tempat bertugas }\end{array}$ \\
\hline 3 & $\begin{array}{l}\text { Kamis, } 3 \text { September } 2020 \\
08.00-12.00(4,0 \text { jam })\end{array}$ & $\begin{array}{l}\text { Menghitung Daya Beda, Dan } \\
\text { Tingkat Kesulitan Soal Nara } \\
\text { Sumber:, Dra. Rispawati,M.Si } \\
\text { dan I Gede Agus Tripayana, } \\
\text { S.Pd., M.Pd }\end{array}$ & Individual & $\begin{array}{l}\text { Rumah masing-masing atau } \\
\text { tsekolah tempat bertugas }\end{array}$ \\
\hline 4 & $\begin{array}{l}\text { Jum'at 4 September } 2020 \\
08.00-12.00\end{array}$ & $\begin{array}{l}\text { Menghitung Tingkat Kesulitan } \\
\text { Soal } \\
\text { Nara Sumber: I Gede Agus } \\
\text { Tripayana, S.Pd., M.Pd dan } \\
\text { Dra. Rispawati, M.Si }\end{array}$ & Individual & $\begin{array}{l}\text { Rumah masing-masing atau } \\
\text { sekolah tempat bertugas }\end{array}$ \\
\hline 5 & $\begin{array}{l}\text { Senin 14 September } 2020 \\
08.00-10.00\end{array}$ & $\begin{array}{l}\text { Berdiskusi terkait menghitung } \\
\text { validitas Soal } \\
\text { Nara Sumber: Drs. Hariyanto, } \\
\text { M.Pd dan I Gede Agus } \\
\text { Tripayana, S.Pd., M.Pd }\end{array}$ & $\begin{array}{l}\text { Semua } \\
\text { peserta }\end{array}$ & $\begin{array}{l}\text { Dari rumah masing-masing } \\
\text { atau sekolah dan Ruang } \\
\text { Dosen PPKn FKIP UNRAM }\end{array}$ \\
\hline 6 & $\begin{array}{l}\text { Selasa } 15 \text { September } 2020 \\
08.00-10.00 \\
(2,0 \text { jam })\end{array}$ & $\begin{array}{l}\text { Berdiskusi terkait menghitung } \\
\text { reliabilitas soal } \\
\text { Nara Sumber: Dra. Rispawati, } \\
\text { M.Si dan Ahmad Fauzan, } \\
\text { S.Pd., M.Pd }\end{array}$ & $\begin{array}{l}\text { Semua } \\
\text { peserta }\end{array}$ & $\begin{array}{l}\text { Dari rumah masing-masing } \\
\text { atau sekolah dan Ruang } \\
\text { Dosen PPKn FKIP UNRAM }\end{array}$ \\
\hline 7 & $\begin{array}{l}\text { Rabu } 16 \text { September } 2020 \\
08.00-10.00 \\
(2,0 \text { jam })\end{array}$ & $\begin{array}{l}\text { Berdiskusi menghitung daya } \\
\text { beda soal } \\
\text { Nara Sumber: Ahmad Fauzan, } \\
\text { S.Pd., M.Pd dan I Gede Agus } \\
\text { Tripayana, S.Pd., M.Pd }\end{array}$ & $\begin{array}{l}\text { Semua } \\
\text { peserta }\end{array}$ & $\begin{array}{l}\text { Dari rumah masing-masing } \\
\text { atau sekolah dan Ruang } \\
\text { Dosen PPKn FKIP UNRAM }\end{array}$ \\
\hline 8 & $\begin{array}{l}\text { Kamis } 17 \text { September } 2020 \\
08.00-10.00 \\
(2,0 \text { jam })\end{array}$ & $\begin{array}{l}\text { Berdiskusi menghitung tingkat } \\
\text { kesulitan soal } \\
\text { Nara Sumber: Drs. Hariyanto, } \\
\text { M.Pd dan Drs. M Ismail, } \\
\text { M.Pd }\end{array}$ & $\begin{array}{l}\text { Semua } \\
\text { peserta }\end{array}$ & $\begin{array}{l}\text { Dari rumah masing-masing } \\
\text { atau sekolah dan Ruang } \\
\text { Dosen PPKn FKIP UNRAM }\end{array}$ \\
\hline & \multicolumn{4}{|l|}{ Total: 24 Jam } \\
\hline
\end{tabular}


Kegiatan pelatihan diawali dengan menanyakan kepada 15 orang Guru PPKn SMPN Se Kota Mataram, apakah ada yang pernah menganalisis soal yang dibuat dan diterapkan pada ujian midsemester maupun akhir semester. Secara aklamasi para peserta belum pernah melakukan dan sangat bersyukur dan berterima kasih atas fasilitas kegiatan pengabdian kepada masyarakat dalam bentuk Pendidikan Dan Latihan ini. Bahkan para peserta memiliki kesempatan untuk dapat mengikuti kegiatan "Pengembangan Materi Pembelajaran Berbasis Soal Pilihan Ganda".

Pada tahap awal materi yang disajikan berupa bagaimana cara mengetahui validitas suatu item soal yang dapat diketahui melalui cara rasional dan emperis. Mengetahui validitas item soal secara rasional dijelaskan agar guru sangat memperhatikan kata kerja Indkator Pencapaian Kompetensi agar konsisten dengan batang tubuh atau stem soal. Hal ini dilakukan agar guru yang agak alergi dengan hitung-hitungan akan dengan serius berusaha membuat soal sesuai kisi-kisi soal. Selanjutnya cara mengetahui cara mengetahui validitas item soal secara rasional, juga dapat dilakukan.

Faktor pendukung suksesnya dalam pelaksanaan Pendidikan Dan Latihan Menghitung Validitas, Reliabilitas, Daya Beda Dan Tingkat Kesulitan Soal Bagi Guru PPKn SMA Negeri Se Kota Mataram diantaranya:

1. Mendapat dukungan dari Ketua Musyawarah Guru Mata Pelajaran PPKn Kota Mataram

2. Mendapat apresiasi dari 15 Kepala Sekolah SMA Negeri Se Kota Mataram, sehingga yang diundang 15 Orang dan oleh karenanya dikirim masing-masing seorang guru, sehingga yang hadir 15 orang peserta

3. Tim menyediakan Hand-Out dengan dilengkapi contoh yang jelas bagaimana cara menghitung validitas, reliabilitas, daya beda, dan tingkat kesulitan

4. Fasilitas ruang yang sangat memadai dan kondisi yang nyaman dan dingin

5. Mendapat dukungan dari Ketua Program Studi PPKn dan Ketua Jurusan Pendidikan IPS FKIP Universitas Mataram

6. Pertama kali dapat melibatkan 2 orang mahasiswa Program Studi PPKn.

7. Peserta difasilitasi pulsa untuk Ketua MGMP sebesar Rp 200.000, sedangkan peserta masingmasing Rp 100.000.
8. Sebagian kecil terutama Guru PPKn SMA Negeri 1 Mataram telah memiliki Program Analisis Test.

9. Peserta menyadari pentingnya pengetahuan yang sangat terkait dengan mutu soal.

10. Dukungan dana PNBP mencair tepat waktu, Wakil Dekan I Fakultas Keguruan Dan Ilmu Pendidikan Universitas Mataram.

Faktor penghambat terlaksananya kegiatan pengabdian kepada masyarakat sebagai berikut:

1. Waktu pelaksanaan tidak bisa dilakukan dengan tatap muka, karena Covid 19 dan oleh karenanya lewat WhatsApp.

2. Dana yang disetujui pihak Tim Fakultas sangat terbatas.

Pertanyaan yang berkembang di anatara peserta adalah sebagai berikut:

1. Apakah materi pengabdian yang disajikan dalam kegiatan ini dapat digunakan untuk menganalisis soal bentuk uraian.

2. Mengapa proporsi soal yang ideal harus $50 \%$ mudah, $30 \%$, dan sulit $20 \%$.

3. Mengapa untuk menganalisis data hasil ujian cukup diambil 27,5\% dari Kelompok Atas (Kelompok Pandai) dan 27,5\% Kelompok Bawah (Kelompok Lemah).

Secara teoritis rumus yang diberikan untuk menghiting validitas, reliabilitas, tingkat kesulitas, daya beda dapat digunkan untuk hasil ujian soal uraian, dengan cara memasukkan skore masingmasing soal dan setiap siswa. Alasan proporsi tersebut untuk menjawab Teori Ketuntasan menurut Benyamin S Bloom yang mengatakan bahwa ketuntas belajar baru dikatakan tercapai jika setiap siswa mampu mencapai minimal $75 \%$. Dengan porsi $50 \%$ soal mudah dan $30 \%$ soal sedang, maka semua siswa diharapkan mampu mencapai minimal ketuntasan belajar $75 \%$. Sedangkan mengapa hanya cukup mengambil $27,5 \%$ kelompok pandai dan 27,5 \% kelompok lemah, terkait dengan pendapat Robert M Dale yang mengatakan bahwa untuk menganalisis validitas, reliabilitas, tingkat kesulitas, dan daya beda paling ideal. Disisi lain lain guru tidak perlu menganalisis seluruh total peserta ujian dan kelompok tengah harus diabaikan karena tidak bersifat ekstrim pandai dan juga tidak lemah.

Kualitas soal buatan guru PPKn SMA Negeri Se Kota Mataram merupakan upaya yang 
harus dilakukan agar evaluasi sebagai komponen proses belajar mengajar fungsional. Dengan demikian kemampuan untuk menghitung validitas, reliabilitas, daya beda, dan tingkat kesulitan soal meruapak standar minimal terkait dengan kewajiban dan kebutuhan guru dalam melaksanakan tugasnya sebagai guru yang profesioanl. Kualitas soal yang digunakan guru baik, akan berimbas pada hasil pengukuran terhadap hasil belajar siswa yang dapat dipertanggung jawabkan kepada semua pihak. Menyadari tidak semua guru suka hitungan statistic, maka banyak guru hanya mengandalkan validitas dan reliabilitas soal secara rasional saja dengan tukar pikiran di antara guru PPKn dalam wadah Musyawarah Guru Mata Pelajaran PPKn. Dengan disediakan materi pengabdian kepada masyarakat secara rinci renik, maka kegiatan Pendidikan Dan Latihan menghitung Tingkat Kesuliatan dan Daya Beda soal disertai contoh menghitung validitas dengan uji product moment dan uji reliabilitas testretest dengan uji product moment menjadi sangat menarik dan menjadi tantangan tersendri bagi masing-masing peserta.

Soal sebagai alat evaluasi dan komponen proses belajar mengajar harus fungsional terhadap keseluruhan system. Dengan demikian harus dijadikan prinsip bahwa Indikator Pencapaian Kompetensi harus sama dan sebangun dengan materi pembelajaran, serta sama dan sebangun dengan soal sebagai alat evaluasi untuk mengukur hasil, proses, dan produk pembelajaran. Para siswa jangan sampai hanya mengerjakan soal yang mudah saja atau jangan sampai tidak bisa menjawab soal, karena tidak pernah diajarkan oleh guru.

Menyadari bahwa validitas item soal dapat dilakukan secara rasional maupun emperis, maka blue print test meruapakan hal penting harus dibuat oleh guru. Dengan demikian soal yang dibuat harus berdasarkan: (1) Kompetensi dasar, (2) Indikator Pencapaian Kompetensi, (3) Materi Pokok, (4) Uraian Materi, (5) Tingkatan Kognitif, (6) Soal, (7) Nomor Soal, dan (8) Kunci Jawaban. Disisi lain yang perlu mendapat perhatian seksama bahwa option (pilihan alternative jawaban harus sejenis dan di antaranya ada yang berfungsi sebagai pengecoh (distractor) untuk menemukan kunci jawaban yang benar.

Pemahaman guru PPKn SMAN tentang cara menghitung validitas, reliabilitas, tingkat kesulitan, dan daya beda soal dikarenakan setiap penelitian kuantitatif menunut syarat bahwa instrument penelitian harus valid, reliable, tingkat kesulitan soal dan daya beda soal harus memenuhi kriteria baik. Selanjutnya dengan memiliki kelompok Bank Soal PPKn SMA untuk semester ganjil dan semester genap, maka guru tidak perlu lagi setiap semester membuat soal. Hal terpenting disamping dikelompokan menjadi Bank Soal semester ganjil dan semester genap, guru juga mengklasifikasikan ke dalam soal yang mudah, sedang, dan soal yang sulit. Dengan soal yang memenuhi syarat validitas, reliabilitas, proporsi soal mudah, sedang, dan yang sulit proporsional, maka hasil belajar siswa akan benar-benar menggambarkan tingkat kecerdasannya dalam mengikuti proses pembelajaran PPKn.

\section{Kesimpulan}

Berdasarkan uraian di atas dapat ditarik beberapa kesimpulan sebagai berikut:

1. Pemahaman guru PPKn SMPN Se Kota Mataram tentang menghitung tingkat kesulitan dan daya beda soal, merupakan kebutuhan guru sekaligus kewajiban untuk memiliki kualitas soal yang baik.

2. Rintisan Bank Soal PPKn SMPN Se Kota Mataram baru dapat dilakukan, jika validitas, reliabilitas soal, tingkat kesulitan soal, dan daya beda soal telah diketahui.

3. Materi pengabdian kepada masyarakat terlampir dapat digunakan baik untuk soal pilihan ganda maupun soal uraian.

\section{Ucapan Terimakasih}

Terimkasih kami ucapkan kepada Rektor Universitas Mataram yang telah memberikan fasilitas berupa pendanaan untuk pelaksanaan pengabdian kepada masyarakat dapat berjalan dengan lancar. Selanjutnya ucapan terimakasih kepada Ketua LPPM, Dekan FKIP, Ketua Jurusan, Ketua Prodi, serta semua pihak yang tidak dapat kami sebutkan satu persatu yang telah banyak membantu kami dalam menyelesaikan pengabdian ini. 


\section{Daftar Pustaka}

Ghony Djunaidi M. 1985. Pedoman Di Dalam Penelitian \& Penilaian. Surabaya: Usaha Nasional

Hariyanto. 1984. Penilaian Hasil Belajar Pendidikan Moral Pancasila. Mataram: FKIP niversitas Mataram

Netra IB. 1974. Statistik Inferensial. Surabaya: Usaha Nasional

Zainul Asmawi dan Mulyana Agus. 2004. Tes Dan Asesmen Di SD. Jakarta: Pusat Penerbitan Universitas Terbuka

Fauzan, A., Rispawati, R., \& Salam, M. (2021). Pengaruh Model Pembelajaran Think Pair Share Terhadap Kemampuan Berpikir Kritis Siswa pada Mata Kuliah Demokrasi Pancasila. Journal of Moral and Civic Education.

https://doi.org/10.24036/8851412512020503 